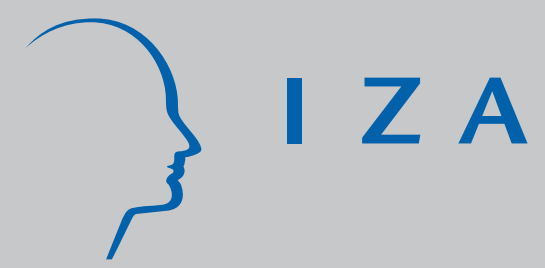

IZA DP No. 7572

Regional Determinants of Establishments' Innovation Activities: A Multi-Level Approach

Lutz Bellmann

Andreas Crimmann

Katalin Evers

Reinhard Hujer

August 2013 


\title{
Regional Determinants of Establishments' Innovation Activities: A Multi-Level Approach
}

\author{
Lutz Bellmann \\ University Erlangen-Nuremberg, IAB and IZA \\ Andreas Crimmann \\ Institute for Employment Research (IAB) \\ Katalin Evers \\ Institute for Employment Research (IAB) \\ Reinhard Hujer \\ Goethe University Frankfurt am Main and IZA
}

Discussion Paper No. 7572

August 2013

IZA
P.O. Box 7240
53072 Bonn
Germany

Phone: +49-228-3894-0

Fax: +49-228-3894-180

E-mail: iza@iza.org

\begin{abstract}
Any opinions expressed here are those of the author(s) and not those of IZA. Research published in this series may include views on policy, but the institute itself takes no institutional policy positions. The IZA research network is committed to the IZA Guiding Principles of Research Integrity.

The Institute for the Study of Labor (IZA) in Bonn is a local and virtual international research center and a place of communication between science, politics and business. IZA is an independent nonprofit organization supported by Deutsche Post Foundation. The center is associated with the University of Bonn and offers a stimulating research environment through its international network, workshops and conferences, data service, project support, research visits and doctoral program. IZA engages in (i) original and internationally competitive research in all fields of labor economics, (ii) development of policy concepts, and (iii) dissemination of research results and concepts to the interested public.
\end{abstract}

IZA Discussion Papers often represent preliminary work and are circulated to encourage discussion. Citation of such a paper should account for its provisional character. A revised version may be available directly from the author. 


\section{ABSTRACT}

\section{Regional Determinants of Establishments' Innovation Activities: A Multi-Level Approach ${ }^{*}$}

This paper analyses the determinants of different innovation types. Beside a wide range of firm characteristics also the effects of regional factors are estimated using three-level random effect logit models which account for the clustered and longitudinal structure of the data. The analyses contain three regional variables: the unemployment rate, the assessment of the region with reference to proximity to research and technology centres and universities and the rate of graduates in mathematics, informatics, natural sciences and technological sciences (MINT-graduates). The empirical basis is the IAB-Establishment Panel Survey 2006 to 2010. Process and radical innovations are significant affected by the unemployment rate and the share of MINT-graduates. The unemployment rate has also for some of the innovation combos a significant effect. The proportion of MINT-graduates is relevant for the probability of all 4 innovation types simultaneously.

JEL Classification: D21, O30, R15

Keywords: determinants of innovation, regional effects, multilevel modelling

Corresponding author:

Lutz Bellmann

Research Department Establishments and Employment

Institute for Employment Research of the Federal Employment Agency

Regensburger Str. 104

90478 Nuremberg

Germany

E-mail: Lutz.Bellmann@iab.de 


\section{Introduction}

During the past three decades the theoretical and empirical research on regional innovation networks has grown significantly. In this context one important topic was the estimation of the impacts of Research \& Development subsidies to stimulate innovation activities on the establishment level in order to assess innovation policy programs and to address regional inequalities. Other interesting research fields are the measurement of the efficiency of regional innovation systems, the empirical analysis of their determinants and the modelling and analyzing of information and knowledge exchange processes in regional networks, e.g. cooperation with research institutes. Also the estimation of the spillovers of specific economic and labour market conditions, e.g. the qualification of employees, is of great importance for an assessment of the local competitiveness in regional innovation systems (AUDRETSCH and FELDMAN, 1996; COOKE, 2001; DOLOREUX and PARTO, 2005; FRITSCH and KAUFFELD- MONZ, 2010; KAUFFELD-MONZ and FRITSCH, 2010; ASHEIM, SMITH and OUGHTON, 2011; FRITSCH and SLAVTCHEV, 2011; SMITH and WATERS, 2011).

The Regional Innovation System (RIS) has become an important analytical framework for advancing our understanding in the innovation processes and patterns experienced by firms and industries at the regional level. A Regional Innovation System is characterized by co-operation in innovation activity between firms and knowledge creating and diffusing organizations, such as universities, training organizations, R\&D institutes and technology transfer agencies (COOKE, 2001; DOLOREUX and PARTO, 2005).

This paper presents a new approach to identify determinants of innovations on the regional level. We analyse in detail which intra- and extra-firm factors simultaneously influence the probability of innovations. With a three level model we mainly focus on the role of the regional determinants of innovations on the firm level. Thus, we follow the argument that the regional embedding of establishments plays an important role for their innovation activities. To the best of our knowledge, our study is the first one that uses the share of graduates in the MINT-disciplines as an indicator for the innovation ability of the region in the sense of the availability of the required labour resources. The MINT-disciplines are jobs in mathematics, informatics, sciences, and engineering. We also consider the innovation ability of the regions measured by the distance to research and technology centres and universities as explanatory factors. We expect positive effects from both ability-variables on the innovation activities of the establishment. As a third regional factor the unemployment rate in the region is also used as explanatory variable in the analysis. The unemployment rate indicates the labour market and employment situation of a region. It is also a novelty to analyse more types of innovations and innovation combinations. Thus, comparisons between the different categories are possible and desirable.

Beside the regional aspect we also use a wide range of establishment's characteristics to explain the innovation activities of establishments in Germany. For the adequate consideration of both firm and region effects we use multi-level approaches. To the best of our knowledge, only one similar approach has so far been used for the Czech Republic (SHROLEC, 2010). Another way to take both firm and region effects into account is using dummies for different spatial units. FRITSCH and FALCK (2007) do so by the analysing of the determinants of new business formation by industry over space and time.

The paper is organized as follows: In Section 2, we discuss the theoretical background and related research. In Section 3, we specify and describe the economic model. Section 4 contains the 
description of the data basis and the descriptive results. Section 5 presents the empirical results. Finally, policy implications and conclusions are drawn in Section 6.

\section{Theoretical background and related research}

The traditional measurements of innovation are mainly R\&D expenditures and patents. But R\&D expenditures indicate only a major input in the innovation progress whereas patents only cover innovations that are sufficiently new, but not all of them are introduced in the market. Also not all innovations necessarily lead to a patent perhaps because of administrative restraints. The OECD OSLO Manual was developed in order to complement patents and bibliometric indicators and R\&D surveys with the aim to characterize firm's innovation progress. It provides among other things indicators of innovation output (MAIRESSE and MOHNEN, 2010).

The term "innovation" can be defined in various ways. From an objective viewpoint a new product is regarded as an innovation if it is new to the relevant market. The subjective approach implies that products, processes and methods that firms are the first to develop and those that have been adopted from other firms or organisations are defined as an innovation. Since its 2005 revision, according to the OECD OSLO Manual one can distinguish between four types of innovations using the subjective approach: The introduction of new products and new processes, organizational changes and marketing innovations (OECD, 2005). The minimum requirement for an innovation is that the product, process, marketing method or organisational method must be new (or significantly improved) to the firm. This approach does not contain information about particular innovation projects.

Research based on establishment-level surveys benefit from the possibility to collect comprehensive data at the decision making level of firms. Another advantage is that the subjective approach is less demanding than the objective approach. Using the subject approach avoids on the one hand specific difficulties to identify, compare and assess individual innovations. On the other hand innovation projects of a firm are taken completely into account if they are introduced, no matter if they are successful or not. (MAIRESSE and MOHNEN, 2010)

Many empirical studies are focused on complementarities between different innovation strategies. There is evidence that firms tend to innovate simultaneously in products and processes (CABAGNOLS and LE BAS, 2002; MARTINEZ-ROS and LABEAGA, 2002; MIRAVETE and PERNIAS, 2006). POLDER et al. (2009) find complementarities between product and process innovations in the manufacturing sector in the Netherlands and other complementarities in other sectors. Firms tend to build up own knowledge, as well as acquire external knowledge. For the ability to absorb extra-firm knowledge it is necessary to provide intra-firm innovative capacity (CASSIMAN and VEUGELERS, 2006; LOKSHIN et al., 2008; VEUGELERS, 1997).

The unequal distribution of innovations in different regions of an economy, especially their concentration in certain locations (e.g. FELDMAN, 1994; PACl and USAI, 1999, 2000; MORENO et al., 2005) are indicators of the relevance of the availability and the quality of local inputs and knowledge spillovers (AUDRETSCH and FELDMAN, 1996; GREUNZ, 2003; FRITSCH and SLAVTCHEV, 2007). But even if the inputs are identical, innovation results differ between regions due to variations in the efficiency of regional innovation systems (RIS). FRITSCH and SLAVTCHEV (2011) found a number of 
factors that have an effect on RIS efficiency. R\&D activity seems to be more productive in agglomerations and RIS are more efficient in West Germany compared to East Germany. The results suggest that RIS performance is strongly influenced by the level and quality of interaction and exchange between its different elements (FRITSCH and SLAVTCHEV, 2011). BROEKEL (2011) investigates the impact of R\&D subsidies on regional innovation efficiency for 270 German labour market regions and four industries. He shows that inter-regional cooperation by R\&D facilities are more important for regions with large innovation capacities, while regions with low innovation capacities benefit from subsidies' inter-regional cooperation.

The role of universities in the innovation process is a topic of many empirical studies. They are seen to have an impact through the generation and diffusion of scientific knowledge in the region. KAUFFELD-MONZ and FRITSCH (2010) identified public research organisations to be the main knowledge broker in regional innovation systems. FRITSCH and SLAVTCHEV (2007) concentrate on university R\&D. They find evidence for West Germany that not the quantity of universities (measured in existence or size) but the quality of universities (measured in external funds) has an impact on innovation output measured by the number of patents. But not only universities also private sector $R \& D$ plays a key role. The authors find a strong significant impact of private sector R\&D employment on innovative output of a region. These findings are in line with a number of studies, which measure innovation output of regions indicated by the number of patents and analyse the output elasticity for private sector and for university R\&D (e.g. JAFFE, 1989; ACS, AUDRETSCH and FELDMAN, 1992; PIERGIOVANNI, SANTARELLI and VIVARELLI, 1997; ANSELIN, VARGA and ACS, 1997; BLIND and GRUPP, 1999; PIERGIOVANNI and SANTARELLI, 2001; AUTANT-BERNARD, 2001; FISCHER and VARGA, 2003; ANDERSSON and EJERMO, 2004; RONDE and HUSSLER , 2005; BARRIO-CASTRO and GARCIAQUEVEDO, 2005). These papers have the aim to explain the innovation ability of a region but not the innovativeness of the establishments in the region. Furthermore, it has not been taken into account that patents are not necessarily equivalent with innovations.

The questions of whether and how the regional environment influence firms' innovation activities also play a key role in the literature. How do the RIS, formed by the specific factors related to the spatial unit, affect innovation activities of establishments? There are many studies which argue that firm characteristics are more important for the innovation success than the location of firms (STERNBERG and ARNDT, 2001). Sectoral differences are particularly important: Firms in the service sector and manufacturing firms differ in the way they are embedded into their regional surroundings and the extent in which they exploit them (CZARNITZKI and HOTTENROTT, 2009). In an empirical study for Europe DE DOMINICIS, FLORAX and DE GROOT (2011) found that both social capital and geographical proximity are important determinants in explaining the differences in the production of innovative output across European regions.

The regional context of innovation is typically considered by including spatial dummies in models estimated on micro-data or by conducting the analysis only with data at a regional level. SRHOLEC (2010) is the first to use a multilevel modelling approach for analysing the determinants of innovations. Using data from the third Community Innovation Survey for the Czech Republic he finds that the quality of the regional innovation system directly influences the likelihood of a firm to innovate (in the sense of introducing a new product or process). Also, broader social characteristics of the region are relevant explanatory factors of innovations. 


\section{Econometric method: Three-level model}

This paper analyses the impact of the regional context and firm characteristics on the probability to implement different innovation activities of establishments in Germany during the time period 2007 until 2009. The various categories of innovations, e.g. process innovation or imitation, are modelled as binary variables. For this reason, the probability of innovation measures will be estimated using logit models. The multi-level model accounts for the clustered and longitudinal structure of the data with annual observations of firms and firms nested in regions. (RABE-HESKETH and SKRONDAL, 2012). Firm characteristics are available at the micro level, whereas regional data are observed at the aggregate level. Multi-level models allow for the grouping of within regions and consider residuals at establishment and regional level. The residuals at regional level represent unobserved characteristics which lead to correlations between outcomes for establishments from the same region. Traditional regression analysis considers these observations as independent, however this assumption is violated and the standard errors are underestimated. For the same reason represent the residuals on establishment level unobserved characteristics which lead to correlations between outcomes for observations from the same establishments.

In the econometric literature, this problem of within-group correlation is known as the Moulton problem (MOULTON 1986, 1990). Establishments within the same region share background characteristics and are exposed to similar general economic conditions that are neither covered by observed firm characteristics nor by observed regional indicators. Therefore, it is prudent to assume that the error terms of the firms in the same region are correlated with each other (intra-class correlation) leading to wrong (typically downward biased) estimates of the standard errors (BLIEN 2005; CAMERON and MILLER, 2010).

Therefore, multi-level approaches are suitable for modelling cross-level interaction effects between variables located at different levels. For the empirical analysis we use a random effects model, because this methodological approach considers both between effects and within effects. The fixed effects model takes into account only the within estimates and eliminates time-constant explanatory variables which are important for the empirical findings. Because of the small cases of establishments in some regions and three observations at most per establishment, we assume fixed slopes and estimate a three-level logistic random intercept model (RABE-HESKETH and SKRONDAL, 2012). The model for clustered longitudinal data with observation $i$ (level 1 ) for establishment $j$ (level 2) nested in region $\mathrm{k}$ (level 3) can be written as a latent response model in a three-stage formulation:

Level 1: $y_{i j k}^{*}=\pi_{1 j k}+\beta_{2} x_{2 i j k}+\beta_{3} x_{3 i j k}+\cdots+\varepsilon_{i j k}$

The intercept $\pi_{1 j k}$ varies between establishments $\mathrm{j}$ and regions $\mathrm{k}, x_{2 i j k}, x_{3 i j k}, \ldots$ denote the covariates at level 1 and $\varepsilon_{i j k}$ is the residual term.

Level 2: $\pi_{1 j k}=\gamma_{11 k}+\gamma_{12} w_{2 j k}+\gamma_{13} w_{3 j k}+\cdots+u_{j k}^{(2)}$

with $w_{2 j k}, w_{3 j k}, \ldots$ covariates at level 2 .

Level 3: $\gamma_{11 k}=\delta_{111}+\delta_{112} v_{2 k}+\delta_{113} v_{3 k}+\cdots+u_{k}^{(3)}$

where $v_{2 k}, v_{3 k}, \ldots$. are covariates at level 3 
Substituting the model for $\gamma_{11 k}$ into the level-2 model and subsequently for $\pi_{1 j k}$ into the level-1 model, we obtain:

$y_{i j k}^{*}=\delta_{111}+\beta_{2} x_{2 i j k}+\beta_{3} x_{3 i j k}+\cdots+\gamma_{12} w_{2 j k}+\gamma_{13} w_{3 j k}+\cdots+\delta_{112} v_{2 k}+\delta_{113} v_{3 k}$

$+\ldots+u_{j k}^{(2)}+u_{k}^{(3)}+\varepsilon_{i j k}$

The general three-level logistic random intercept model can be written as follows:

$y_{i j k}^{*}=\alpha_{1}+Z_{i j k}^{\prime} \boldsymbol{\alpha}+u_{j k}^{(2)}+u_{k}^{(3)}+\varepsilon_{i j k}$

$y_{i j k}=1$ if $y_{i j k}^{*}>0$ and $y_{i j k}=0$ if $y_{i j k}^{*}$ otherwise

$Z_{i j k}=\left(x_{2 i j k}, x_{3 i j k}, \ldots, w_{2 j k}, w_{3 j k}, \ldots, v_{2 k}, v_{3 k}, . .\right)^{\prime}$ denotes a vector of all covariates and $\boldsymbol{\alpha}=\left(\beta_{2}, \beta_{3}, \ldots, \gamma_{12}, \gamma_{13}, \ldots, \delta_{112}, \delta_{113}, \ldots\right)$ contains the fixed slopes of the random intercept model. Furthermore $u_{j k}^{(2)} \mid Z_{i j k}, u_{k}^{(3)} \sim N\left(0, \psi^{(2)}\right)$ is a random intercept varying over firms (level 2), and $u_{k}^{(3)} \mid Z_{i j k} \sim N\left(0, \psi^{(3)}\right)$ a random intercept varying over regions (level 3$)$. The random effects $u_{j k}^{(2)}$ and $u_{k}^{(3)}$ are assumed to be independent of each other and across clusters and independent of the residual error term $\varepsilon_{i j k}$.

The residual error term $\varepsilon_{i j k} \mid Z_{i j k}, u_{k}^{(3)}, u_{j k}^{(2)}$ is assumed to have a logistic distribution with mean zero and variance $\pi^{2} / 3$ :

$\operatorname{Pr}\left(\varepsilon_{i j k} \mid Z_{i j k}, u_{k}^{(3)}, u_{j k}^{(2)}\right)=\operatorname{logit}\left\{\operatorname{Pr}\left(y_{i j k}=1 \mid Z_{i j k}, u_{j k}^{(2)}, u_{k}^{(3)}\right)\right\}$

An independent covariance structure for the random effects is assumed. It allows a distinct variance for each random effect within the random-effects equation.

Random-effects models implicitly assume that between-cluster and within-cluster effects of the covariates are the approximately same (RABE-HESKETH and SKRONDAL 2012). Many empirical studies show that within-estimates (using fixed-effects panel models) get closer to the true causal effect by eliminating cluster-specific unobserved heterogeneity. Fixed-effects estimates circumvent the problem of cluster-level confounding and restrict the problem of endogeneity and ecological fallacy.

However, the 'general' effect will be more precisely estimated using both within and between variations. This holds true if there are no differences in the between and within effects of the covariates on innovation activities. For this reason, we test whether there are differences in the between and within effects of the regional covariates of interest. In the case of significant differences, within effects are included in the model in conjunction with between effects (see RABEHESKETH and SKRONDAL, 2012). 


\section{Data and descriptives}

For the empirical analysis we used data from the IAB Establishment Panel. The IAB Establishment Panel is an annual survey of approx. 16.000 establishments. It represents all industries and establishment sizes in Germany. The establishments are interviewed about a large number of employment policy-related subjects, including employment development, business policy and business development, investment activities, innovations in the establishment, public funding, personnel structure, vocational training and apprenticeships, new and existing personnel, recruitment, wages and salaries, working times in the establishment, further training and general data on the establishment. For further information on these data see FISCHER et al. (2009). In order to include only relatively homogenous sectors in the analysis the secondary sector had been chosen, as innovations in the service sector are quite different. Furthermore, the analyses only include private establishments (see Appendix 1).

We analyse innovation activities of german firms in the years 2007, 2008 and 2009 by using the waves 2008, 2009 and 2010 of the IAB establishment panel. Since the wave of 2008, the questions regarding innovations refer to the "previous business year". In the waves before 2008, the information refers to the "last 2 year". This was the main reason for starting with the wave 2008 . The IAB-Establishment Panel used the subjective concept of innovation. Four types of innovation can be distinguished in this survey: entirely new products, incremental innovations, imitations and process innovations. The innovation concepts used correspond to the definitions in the OSLO Manual (see OECD, 2005). In the innovation process, which comprises the phases of idea generation, invention, implementation and diffusion, it is therefore the introductory phase that is important - and not market penetration. The survey records the types of innovations that the establishment was able to implement during the reference period. The number of innovations, however, is not of importance.

Radical innovations are new products from the viewpoint of the innovative firm and the market. They are thus regarded as innovations according to both the subjective and the objective definition. A radical innovation is an entirely new service or a new product for which a new market has to be created.

Imitations are innovations from the viewpoint of the innovative firm. Unlike radical innovations, however, the products or services supplied by the innovator for the first time are already available on the market in the same or a similar form. The applications and possible uses or the product technology therefore already exist in a comparable or modified form.

Incremental innovations are improvements or developments of an existing product or an existing service. As incremental innovations generally aim at maintaining competitiveness, they are usually not accompanied by any substantial changes in the technology or the market.

Process innovations are procedures developed or introduced in the firm, which have significantly improved the production process or the provision of services. These are generally changes in manufacturing techniques and procedures as a result of technological progress.

The incidences of innovations are presented in Table 1 . Approximately $40 \%$ of establishments in the secondary sector had at least one type of innovation in the investigation period between 2008 and 2010. The descriptives show furthermore, that radical innovations are relatively seldom compare to the other innovation types. One out of three German establishments had incremental innovations, between $16 \%$ and $18 \%$ had imitations and between $11 \%$ and $13 \%$ process innovations. 
Furthermore, the discontinuous development is influenced by the economic and financial crisis with its culmination in 2009.

\section{(Table 1 about here)}

However, innovations are predominantly not singular occasions. Between 2008 and 2010 only every $4^{\text {th }}$ establishment $(21 \%$ ) had just one innovation type yearly, as table 2 shows. In $1 / 3$ of all establishments (34\%) at least 2 innovation types were observed. $19 \%$ of the establishments simultaneously had 2 innovation types. $10 \%$ of the establishments quote that they had 3 innovation types and $5 \%$ had all 4 innovation types No observable innovation can be stated in $46 \%$ of all establishments.

(Table 2 about here)

As shown an innovation type is not always independent from other innovation activities at the establishment level. Therefore it is useful to rank the combination of innovation types by their frequency. Rank 1 is comprised of the 5,209 establishments that did not even have one out of the four innovation types. Ranks 2 to 6 are made up of different combinations of incremental innovations (see table 3 ). The most common combination is an incremental innovation- but no other innovation type in the $2^{\text {nd }}$ place. On the $3^{\text {rd }}$ rank are imitations in combination with incremental innovations followed by the combination of incremental innovations and process innovations at the $4^{\text {th }}$ rank. On the $5^{\text {th }}$ rank are imitations, incremental innovations and process innovations. On the $6^{\text {th }}$ rank we can see the combination of all 4 innovation types. Because 9943 of 11425 occasions are dedicated to the first 6 ranks we subsequently consider only these establishments.

(Table 3 about here)

For the investigation of the regional influence on innovation it is essential to have an appropriate regional differentiation. Studies in Regional Economics require functional regions as statistical units. KROPP and SCHWENGLER (2012) compared four different functional and two administrative delineations in their paper: The 150 labour markets from ECKEY et al. (2006), 50 labour-market regions from KROPP and SCHWENGLER (2011), 270 labour-market regions assessed by the Joint Task Force on the "Improvement of the Regional Economic Structure" and 96 administrative regions examined by the Federal Institute for Research on Building, Urban Affairs and Spatial Development, 176 employment agencies of the Federal Employment Agency and 413 city and rural districts. The authors show that a better delineation quality can be achieved when fewer units varying in size measured by the values of modularity- are used. So they suggest to use the 50 labour-market regions from KROPP and SCHWENGLER (2011) because this classification has the highest values in modularity. Disadvantage is that the 50 labour market regions are very heterogeneous regarding area and this makes difficult to compare direct regional units They also argue that the 150 regional labour market from ECKEY et al. (2006) are homogenous regarding area and have the makings of be suitable for regional comparisons. The modularity is here also high. Currently there is a new delineation available which wasn't part of the comparison by KROPP and SCHWENGLER (2012). KOSFELD and WERNER (2012) delineate 141 regional labour markets considering the latest changes in both, the economic and the commuter structure of a country. An advantage of this concept is beside the actuality or the 141 regional labour markets the amount of regions compared to KROPP and SCHWENGLER (2011). Thus the variance in the data is higher and statistically better results can 
be expected. Therefore we use the latest concept of 141 regional labour markets of KOSFELD and WERNER (2012).

Three-level estimation approaches are used in this paper. These levels are 1 . the observation , 2. the establishment and 3.the region. In the binomial multilevel-model the dependent variable is a dummy, that indicates if the defined innovation or the defined combination of innovation types is observable in the establishment ( $1=$ yes). Only if none of the four innovation types is observable does the value become equal to zero $(0=$ non-innovator) in a year (see Table 3$)$.

A wide set of explanatory variables on the firm level is included in the analysis (the descriptive statistics of the variables are presented in Appendix 3). R\&D activities have the aim to generate new products and services. Furthermore, cooperating firms tend to spend more on R\&D (BELDERBOS et al., 2004; KAISER, 2002, MIOTTI and SACHWALD, 2003; TETHER, 2002). Therefore it is controlled for $R \& D$ with a set of three dummyvariables if R\&D activities are observable in the establishment and if the establishment cooperates in this field with partners within the firm or external partners. We lagged all explanatory variables thus they refer to the time before innovation.

Investments might be an indicator for the firm's strategy and are usually necessary for generating of innovations. To assess for the firm's development, we also take plant-expansion investments into account. With four categorical variables, we control whether such investments exist in general and which share they have on the sum total investments. The classification takes places on the basis of the quartiles of the plant-expansion investments.

In addition it is accounted for the export orientation of the establishment as a proxy for international strategies of the firm. It might be possible that firms are more likely to innovate, if the offered goods have to remain competitive on international markets. The quartiles of export shares on sales are considered in the estimations. ROPER and LOVE (2002) find evidence that product innovation have a significant effect on export activities, thus the export variables refer also to the time before innovation.

Technological abilities and physical equipment might limit or enhance mainly process innovations but the production function might have an effect on radical innovations, imitations and incremental innovations. For the technical state of the plant and machinery, furniture and office equipment we include with a set of three dummies. They indicate the technical condition in the establishment to be 1. state of the art, 2. rather new or 3. medium or worse.

Know-how is essential for generating innovations. For this reason the estimations contain the share of qualified employees among all employees as an explanatory variable. It is also controlled for if the establishment supports further training measures. This means both releasing staff for the purpose of participating in internal or external training courses and covering the expense for these in full or at least in part by the establishment.

The economic situation of establishments is described by a set of three dummies that indicate if the firm expects the business volume to increase, remain constant or decrease.

The link between establishment size and innovation activities is well documented in the previous literature (COHEN, 2010; MAIRESSE and MOHNEN, 2010). In the analysis all establishments with at least one employee subject to social security contributions are covered. The establishment size indicated by the sum of employees is included in the estimations in five classified dummy-variables: 1 
to 9 employees, 10 to 49 employees, 50 to 249 employees, 250 to 499 employees, and 500 or more employees.

The motivation to campaign for the employer is influenced by the wage level. Therefore, the logarithmized wage per full-time equivalent is included as an explanatory variable in the estimations.

As a standard the location of the establishment in West- or East-Germany and the sector are considered. The establishment structure between West and East Germany is still shaped by historically different developments. The industries we cover are supply, mining and quarrying as a reference as well as manufacturing of food products, commodities, durables, investment- and consumer goods and construction.

Combining survey and administrative data allows us to identify region specific effects. The unemployment rate indicates the attractiveness of a region for job searchers. The proportion low qualified individuals among the unemployed in Germany is relatively high. Thus, a higher unemployment rate does not necessarily imply that the recruitment of specialists and qualified staff is better in general. Therefore, structurally weak regions having higher unemployment rates can describe the general quality of the region. This interpretation implies a negative relationship between unemployment rate and innovation activities. By including the unemployment rate (UR), calculated as a percentage by dividing the number of unemployed individuals by all individuals currently in the labour force (average rate 2006-2009) in a region, in the estimations we expect a negative effect on innovations.

The regional innovation capability is reflected among other indicators by the amount of research and technology centres. In the estimations we consider a location factor (RTC). It indicates the firm's assessment of the location on a range from 1 (=very good) to 6 (=very bad), concerning the spatial proximity to research and technology centres and universities, as an average grade from all establishments in this region. Due to the diffusion of knowledge we expect that in high-tech-regions innovations are more likely than in other regions.

In Germany a shortage of skilled workers is expected in the so called MINT-disciplines: mathematics, informatics, natural sciences and technological sciences. Therefore, it is a strategic advantage to firms to satisfy the jobs' demand of MINT-graduates. Recruiting is easier if a university is located near the establishment. This link is controlled for, because innovations should be more likely if the share of MINT-graduates higher in one region compared to other regions. The MINT rate is calculated as a percentage by dividing the number of MINT-graduates by all graduates as an average relation between 2006 and 2009 (MINTALLE). (For the description of the regions based on the regional explanatory variables see Appendix 2.)

\section{Empirical results}

Table 4 displays the estimated marginal effects and the standard errors of the unbalanced random intercept three-level models for the four types of innovations. Additionally in the first model probability for "global" innovations is estimated. The random intercept model implicitly assumes that the between and within effects of the set of covariates that vary both between and within levels are identical (RABE-HESKETH and SKRONDAL, 2012). This assumption has been tested for the covariates by using appropriate test for the $H_{0}: \beta_{\text {between }}-\beta_{\text {within }}=0$ for each region. We fit the cluster mean of the explanatories as well as the establishment-specific deviation from the cluster mean of the 
explanatories as covariates an estimate random-intercept models by using these new variables. After that we test the null hypothesis that the corresponding coefficients are the same (RABE-HESKETH, SKRONDAL, 2012)-These tests show - with a few exceptions - no significant differences between within and between effects (Appendix 4). Consequently, the random effects approach is adequate regarding the covariates of interest because it uses both within and between information.

On the regional level a negative effect of the unemployment rate on the innovation probability is observable. A higher regional unemployment rate reduces the probability for both process and radical innovations significantly. The same applies to the combinations 1, 3 and 5 (only incremental innovations; incremental + process innovations; all innovation types). We also regard a higher unemployment rate as an indicator for structural problems of a region. This might reduce the spatial innovation capability in general.

If research and technology centers and universities are well connected in a region, the probability of innovations in general, radical innovations and imitations tend to be higher. By the other types of innovations the marginal effects show negative sign. Unfortunately none of the effects is significant. The proportion of MINT-graduates has a significant impact on the probability of radical and process innovations and for the combination 5 (all 4 innovation types).

Both R\&D activities and investments - especially plant-expansion investments - can be regarded as important pre-stages for innovation and are positive related to the different innovation types.

Compared to establishments without R\&D activities, the high significantly effects increase even more if the establishment furthermore cooperates in this field with external partners. Innovations are as well more likely after plant-investments. The effects and the significances depend on the level of plant-expansion investment on total investments. With increasing share of these investments the correlations become weaker.

Exports have a positive effect on innovation probability. For all innovation forms a higher export share on sales increase significantly the probability. A better technical state of the plant and machinery, furniture and office equipment increases in most estimation at least slightly the innovation probability. A higher share of qualified enhances the probability for innovations in general. This highly significant correlation means that a 10 percentage point higher share of qualified staff increases the probability of innovations by 3 percentage points. Similar effects are observable if the dependent variable is the combination 1 (only incremental innovations): A 10 percentage point higher share of qualified employees increases the probability of only incremental innovations by 6 percentage points. Thus, highly qualified employees might be a hint to improve already existing goods and services but are not a guarantee to generate

Further training measures have in all specifications a highly significant positive effect on the dependent variable. This means that in establishments that offer or support further training measures the innovation probability rises.

In establishments with a nonincreasing expected development of the business volume the innovation probability is significantly lower than in establishments with an increasing expected development. If it is expected that the business volume will remain constant or decrease, the probability of every type of innovation is significant lower. This means that innovation activities are as well determined by the expectation of firm's performance. The firm size as number of employees enhances the innovation probability significantly in all estimations. According to the literature scale effects are 
assumed to improve innovation activities. It is a stylized fact that the wage level is higher in larger firms. The estimation result for the logarithmized wage level per full-time equivalent show only a slight negative significant effect on the probability of the innovation combination 4 (incremental + process innovations + imitations).

Statistically differences are only by radical innovation observable between West- and East-Germany despite the fact that labor market exhibit different features even more than 20 years after reunification. The marginal effect are distinct between sectors in all estimations, only between energy supply, mining and quarrying and the construction sector innovation probability does not differ significantly in some estimations.

The description shown in Chapter 4 reveals that the most cases establishments have more than one type of innovation simultaneously. Hence Table 5 shows the estimated marginal effects for the most common innovation combinations. The effects of the explanatory variables are almost the same as by the four innovation types concerning the size and significance.

\section{Conclusions}

The empirical results show that a range of factors has significant effects for the probability of almost all innovation types or combinations. In contrast regional determinants are relevant for selected innovation types or combos. The unemployment rate has in 5 of 10 estimations a significant negative effect on the probability of the respective type of innovation. A higher share of MINT-graduates increases the probability of radical and process innovations and the simultaneously appear of all 4 innovation types. A better proximity to research and technology centres and universities has no significant effect on the probability of innovations.

The analyses in this paper present the innovation ability of a region as a source of innovation defined not only in a broad sense but also as the introduction of new products new processes and the development of existing products. Using the data of the IAB Establishment Panel Survey 2006-2010 adopt a three-level model for these four types of innovations. Our findings show that the regional variables the proportion of MINT-graduates and the unemployment rate exhibit significant results. Furthermore, for R\&D-activities and investments - as important pre-stages for innovations -, export activities, the proportion of qualified employees as well as the technical state of the plant we get significant results. In addition innovation activities seem to be well determined by the expected performance. These results corroborate those obtained in earlier studies based on methods which do not explicitly take the hierarchical structure of the influencing factors into account. 


\section{Appendix}

\section{Appendix 1}

The secondary sector contains the following industries:

- Energy supply, mining and quarrying. (ref.)

- manufacture of food products

- manufacture of commodities

- manufacture of durables

- manufacture of investment- \& consumer goods

- Construction

Establishments are non-private, if

- the whole establishment/office or parts of it are a non-profit, charitable or religious organisation and therefore eligible for tax relief,

- the establishment is a non industrial organization, regional and local authority etc. and has a budget volume as business volume,

- the legal form of the establishment is a public corporation, public law foundation, institution, authority or office or other legal form (e.g. association or cooperative),

- the establishment is mainly or exclusively in public property,

- the establishment belongs to the industry of non-industrial organizations or public administration. 
Appendix 2

\begin{tabular}{|c|c|c|c|c|c|c|c|}
\hline $\begin{array}{l}\text { Regional labour } \\
\text { market }\end{array}$ & $U R$ & $\begin{array}{c}\text { MINTA } \\
\text { LLE }\end{array}$ & $R T C$ & $\begin{array}{l}\text { Regional labour } \\
\text { market }\end{array}$ & $U R$ & $\begin{array}{c}\text { MINTA } \\
\text { LLE }\end{array}$ & $R T C$ \\
\hline Kiel & 9.54 & 27.2 & 2.79 & Bochum & 13.35 & 30.6 & 2.71 \\
\hline Lübeck & 11.22 & 35.4 & 3.29 & Dortmund & 13.20 & 43.8 & 2.30 \\
\hline Dithmarschen & 10.50 & 19.0 & 4.00 & Hagen & 8.87 & 19.1 & 3.41 \\
\hline Flensburg & 9.84 & 35.0 & 2.63 & Siegen & 7.20 & 31.3 & 2.50 \\
\hline Hamburg & 8.17 & 24.9 & 3.11 & Soest & 8.03 & 38.5 & 2.44 \\
\hline Braunschweig & 9.98 & 56.5 & 2.87 & Darmstadt & 7.37 & 69.2 & 3.42 \\
\hline Wolfsburg & 9.13 & 53.5 & 3.25 & Frankfurt am Main & 7.60 & 27.3 & 2.73 \\
\hline Göttingen & 10.72 & 21.4 & 3.97 & Gießen & 8.25 & 24.7 & 3.30 \\
\hline Goslar & 13.07 & 40.7 & 3.80 & Limburg-Weilburg & 6.44 & 4.0 & 4.00 \\
\hline Hannover & 10.08 & 27.0 & 2.95 & Kassel & 9.47 & 26.1 & 3.33 \\
\hline Hameln & 10.81 & 50.8 & 2.88 & Fulda & 6.92 & 13.2 & 3.45 \\
\hline Celle & 9.60 & 42.0 & 3.67 & Waldeck-Frankenberg & 7.27 & 0.0 & 3.50 \\
\hline Lüchow-Dannenberg & 14.63 & 0.0 & 4.16 & Koblenz & 6.61 & 23.8 & 3.44 \\
\hline Stade & 8.33 & 77.8 & 3.23 & Altenkirchen & 7.00 & 0.0 & 3.27 \\
\hline Uelzen & 9.97 & 100.0 & 3.43 & Bad Kreuznach & 7.98 & 33.2 & 3.00 \\
\hline Emden & 10.87 & 45.4 & 3.00 & Bitburg & 4.47 & 0.0 & 3.33 \\
\hline Oldenburg & 8.67 & 40.5 & 2.76 & Vulkaneifel & 5.60 & 0.0 & \\
\hline Osnabrück & 7.09 & 23.3 & 3.33 & Trier & 5.18 & 30.1 & 3.20 \\
\hline Emsland & 6.25 & 0.0 & 3.84 & Kaiserslautern & 8.22 & 58.2 & 2.67 \\
\hline Wilhelmshaven & 10.80 & 45.2 & 3.00 & Landau & 5.34 & 6.8 & 3.25 \\
\hline Vechta & 6.22 & 15.3 & 3.27 & Ludwigshafen & 7.80 & 20.0 & 2.29 \\
\hline Bremen & 9.24 & 34.4 & 2.59 & Mainz & 7.14 & 23.6 & 2.93 \\
\hline Bremerhaven & 12.59 & 53.9 & 2.78 & Stuttgart & 5.06 & 44.0 & 3.29 \\
\hline Düsseldorf & 9.52 & 30.5 & 3.13 & Böblingen & 4.90 & 0.0 & 3.86 \\
\hline Essen & 12.19 & 26.0 & 2.83 & Göppingen & 5.10 & 46.7 & 2.21 \\
\hline Wuppertal & 11.50 & 42.0 & 3.20 & Heilbronn & 5.19 & 35.1 & 3.75 \\
\hline Kleve & 7.30 & 0.0 & 4.00 & Schwäbisch Hall & 4.30 & 0.0 & 1.50 \\
\hline Bonn & 7.20 & 29.0 & 3.20 & Heidenheim & 5.01 & 46.3 & 3.67 \\
\hline Köln & 10.40 & 18.2 & 2.44 & Karlsruhe & 5.47 & 62.7 & 2.00 \\
\hline Aachen & 10.84 & 60.2 & 2.40 & Heidelberg & 5.91 & 24.3 & 2.75 \\
\hline Olpe & 6.94 & 86.6 & 3.29 & Pforzheim & 5.72 & 9.4 & 4.11 \\
\hline Münster & 6.17 & 25.0 & 2.96 & Freiburg & 5.48 & 21.3 & 2.42 \\
\hline Borken & 6.13 & 41.9 & 3.00 & Ortenaukreis & 4.87 & 40.0 & 3.00 \\
\hline Bielefeld & 8.71 & 29.8 & 2.97 & Rottweil & 4.49 & 51.5 & 2.93 \\
\hline Höxter & 7.50 & 43.2 & 3.00 & Konstanz & 5.37 & 34.7 & 3.17 \\
\hline Minden & 7.79 & 97.8 & 3.41 & Lörrach & 5.27 & 0.0 & 3.13 \\
\hline München & 5.00 & 35.6 & 2.71 & $\begin{array}{l}\text { Mecklenburgische } \\
\text { Seenplate }\end{array}$ & 18.89 & 14.0 & 3.56 \\
\hline Altötting & 5.51 & 0.0 & 4.29 & Rostock & 15.42 & 31.5 & 2.72 \\
\hline Traunstein & 4.61 & 61.2 & 2.50 & Nordvorpommern & 17.87 & 42.0 & 3.75 \\
\hline Weilheim-Schongau & 4.51 & 0.0 & 3.50 & Südvorpommern & 19.58 & 33.6 & 3.32 \\
\hline
\end{tabular}




\begin{tabular}{|c|c|c|c|c|c|c|c|}
\hline $\begin{array}{l}\text { Regional labour } \\
\text { market }\end{array}$ & $U R$ & $\begin{array}{c}\text { MINTA } \\
\text { LLE }\end{array}$ & $R T C$ & $\begin{array}{l}\text { Regional labour } \\
\text { market }\end{array}$ & $U R$ & $\begin{array}{c}\text { MINTA } \\
\text { LLE }\end{array}$ & $R T C$ \\
\hline Deggendorf & 5.88 & 56.7 & 3.40 & Chemnitz & 14.62 & 46.7 & 2.88 \\
\hline Freyung-Grafenau & 6.53 & 0.0 & 3.00 & Dresden & 13.31 & 44.2 & 2.81 \\
\hline Passau & 6.53 & 9.1 & 2.50 & Bautzen & 16.67 & 40.5 & 2.89 \\
\hline Landshut & 4.71 & 39.0 & 4.00 & $\begin{array}{l}\text { Leipzig } \\
\end{array}$ & 16.20 & 27.0 & 3.23 \\
\hline Cham & 5.37 & 0.0 & 4.00 & Dessau-Roßlau & 15.65 & 64.3 & 3.85 \\
\hline Amberg & 7.14 & 44.8 & 3.64 & Magdeburg & 14.46 & 27.3 & 3.27 \\
\hline Regensburg & 5.22 & 31.1 & 3.00 & Halle & 17.47 & 28.6 & 3.57 \\
\hline Bamberg & 5.82 & 10.8 & 2.70 & Stendal & 19.23 & 0.0 & 3.80 \\
\hline Bayreuth & 7.40 & 31.9 & 4.00 & Erfurt & 13.90 & 38.1 & 2.68 \\
\hline Coburg & 8.35 & 46.9 & 2.73 & Gera & 15.87 & 0.0 & 3.30 \\
\hline Hof & 11.07 & 22.8 & 2.91 & Jena & 10.72 & 33.4 & 2.04 \\
\hline Kronach & 6.57 & 0.0 & 3.67 & Nordhausen & 18.27 & 26.4 & 4.18 \\
\hline Erlangen & 4.45 & 37.8 & 1.67 & Eisenach & 10.80 & 0.0 & 3.00 \\
\hline Nürnberg & 7.27 & 32.6 & 2.86 & Unstrut-Hainich & 14.87 & 0.0 & 3.43 \\
\hline Ansbach & 5.11 & 25.2 & 3.00 & Suhl & 10.98 & 37.1 & 3.19 \\
\hline $\begin{array}{l}\text { Weißenburg- } \\
\text { Gunzenhausen }\end{array}$ & 5.60 & 0.0 & 3.67 & Saalfeld-Rudolstadt & 12.39 & 0.0 & 2.92 \\
\hline Aschaffenburg & 5.17 & 27.6 & 3.83 & Märkisch Oderland & 14.93 & 0.0 & 3.35 \\
\hline Schweinfurt & 5.87 & 50.2 & 2.75 & Oberhavel & 14.37 & 0.0 & 3.77 \\
\hline Würzburg & 4.70 & 26.1 & 3.56 & Ostprignitz-Ruppin & 18.10 & 0.0 & 3.33 \\
\hline Augsburg & 6.43 & 25.8 & 2.71 & Potsdam-Mittelmark & 11.89 & 44.0 & 3.74 \\
\hline Memmingen & 3.81 & 0.0 & 2.00 & Prignitz & 17.27 & 0.0 & 4.30 \\
\hline Donau-Ries & 3.67 & 0.0 & 3.00 & Cottbus & 16.42 & 77.0 & 3.47 \\
\hline Kempten & 4.58 & 29.1 & 3.00 & Teltow-Fläming & 12.07 & 0.0 & 3.20 \\
\hline Saarbrücken & 8.84 & 32.8 & 3.23 & Uckermark & 21.70 & 0.0 & 3.86 \\
\hline Pirmasens & 7.83 & 56.3 & 2.95 & Schwerin & 14.00 & 58.3 & 3.78 \\
\hline Berlin & 15.14 & 26.6 & 2.65 & Elbe-Elster & 19.89 & 61.6 & 3.55 \\
\hline Frankfurt (Oder) & 15.29 & 0.7 & 3.04 & Havelland & 13.67 & 0.0 & 3.43 \\
\hline Mean over all regions & \multicolumn{3}{|c|}{ UR: 11.25} & MINTALLE: 32.3 & \multicolumn{3}{|c|}{ RTC: 3.11} \\
\hline
\end{tabular}

Notation: UR: Unemployment Rate (in \%); MINTALLE: Share of MINT-graduates on all graduates (in \%); RTC: Location factor, proximity to research and technology centres and universities, average grade from 1 (very good) to 6 (very bad)

Source: own calculations with data from the Federal Employment Agency, the Federal Statistic Office and the IAB Establishment Panel Survey 


\section{Appendix 3}

Descriptive statistics of the explanatory variables

\begin{tabular}{|c|c|c|}
\hline Variable & Mean & Std. Dev. \\
\hline \multicolumn{3}{|l|}{ Research and Development (R\&D) } \\
\hline - no R\&D in establishment (ref.) & 0.76 & 0.43 \\
\hline - R\&D in establishment without cooperation & 0.04 & 0.19 \\
\hline - R\&D in establishment with cooperation & 0.20 & 0.40 \\
\hline \multicolumn{3}{|l|}{ Share of plant-expansion investment on total investments } \\
\hline - no plant-expansion investment (ref.) & 0.61 & 0.49 \\
\hline - up to 40 percent & 0.14 & 0.35 \\
\hline - more than 40 to 90 percent & 0.15 & 0.36 \\
\hline - more than 90 percent & 0.09 & 0.29 \\
\hline \multicolumn{3}{|l|}{ Export share (on sales) } \\
\hline - no export (ref.) & 0.63 & 0.48 \\
\hline - up to 15 percent & 0.13 & 0.34 \\
\hline - more than 15 to 50 percent & 0.15 & 0.36 \\
\hline - more than 50 percent & 0.09 & 0.29 \\
\hline \multicolumn{3}{|c|}{ Technical state of the plant and machinery, furniture and office equipment } \\
\hline - state-of-the-art (ref.) & 0.15 & 0.36 \\
\hline - rather new & 0.49 & 0.50 \\
\hline - medium or worse & 0.36 & 0.48 \\
\hline Share of qualified employees (in percent) & 68.27 & 25.50 \\
\hline Further training $(d)$ & 0.61 & 0.49 \\
\hline \multicolumn{3}{|l|}{ Expected development of the business volume } \\
\hline - increasing (ref.) & 0.23 & 0.42 \\
\hline - remaining constant & 0.50 & 0.50 \\
\hline - decreasing & 0.26 & 0.44 \\
\hline \multicolumn{3}{|l|}{ Establishment size } \\
\hline - $\quad 1-9$ employees (ref.) & 0.32 & 0.47 \\
\hline - $10-49$ employees & 0.32 & 0.47 \\
\hline - 50-249 employees & 0.23 & 0.42 \\
\hline - 250-499 employees & 0.07 & 0.25 \\
\hline - 500 or more employees & 0.07 & 0.25 \\
\hline Wage per full-time-equivalent (log.) & 7.52 & 0.57 \\
\hline West-Germany (d) & 0.51 & 0.50 \\
\hline \multicolumn{3}{|l|}{ Sector } \\
\hline - Energy supply, mining and quarrying. (ref.) & 0.04 & 0.19 \\
\hline - manufacture of food products & 0.08 & 0.27 \\
\hline - manufacture of commodities & 0.09 & 0.29 \\
\hline - manufacture of durables & 0.22 & 0.42 \\
\hline - manufacture of investment- \& consumer goods & 0.33 & 0.47 \\
\hline - construction & 0.24 & 0.43 \\
\hline UR & 11.12 & 3.99 \\
\hline RTC & 3.11 & 0.28 \\
\hline MINTALLE & 33.67 & 9.06 \\
\hline
\end{tabular}

Note: ref. $=$ reference, $d=$ dummy 
Appendix 4

\begin{tabular}{|c|c|c|c|c|c|c|c|c|c|c|}
\hline $\begin{array}{l}(P>|z|) \text { by } \\
H_{0}: \beta_{\text {between }}-\beta_{\text {within }}=0\end{array}$ & Innovation & \begin{tabular}{|c|} 
Process \\
innovation \\
\end{tabular} & $\begin{array}{c}\text { Radical } \\
\text { Innovation }\end{array}$ & $\begin{array}{l}\text { Incremental } \\
\text { Innovation } \\
\end{array}$ & Imitaion & Combo 1 & Combo 2 & Combo 3 & Combo4 & Combo 5 \\
\hline \multicolumn{11}{|l|}{ R\&D (Ref: no R\&D in establishment) } \\
\hline R\&D in establishment without cooperation & 0.73 & 0.85 & 0.49 & 0.55 & 0.79 & 0.26 & 0.46 & 0.98 & 0.71 & 0.65 \\
\hline R\&D in establishment with cooperation & 0.831 & 0.65 & 0.31 & 0.85 & 0.99 & 0.95 & 0.36 & 0.09 & 0.16 & 0.85 \\
\hline \multicolumn{11}{|c|}{$\begin{array}{l}\text { Share of plant-expansion investment on total } \\
\text { investments (Ref: no plant-expansion investment) }\end{array}$} \\
\hline - up to $40 \%$ & 0.029 & 0.13 & 0.06 & 0.03 & 0.04 & 0.99 & 0.07 & 0.48 & 0.26 & 0.40 \\
\hline - more than $40 \%$ up to $90 \%$ & 0.983 & 0.03 & 0.07 & 0.49 & 0.40 & 0.63 & 0.90 & 0.01 & 0.85 & 0.11 \\
\hline - more than $90 \%$ & 0.279 & 0.05 & 0.72 & 0.78 & 0.29 & 0.13 & 0.67 & 0.49 & 0.86 & 0.77 \\
\hline \multicolumn{11}{|l|}{ Export share on sales (Ref: no export) } \\
\hline - up to $15 \%$ & 0.198 & 0.61 & 0.18 & 0.30 & 0.07 & 0.92 & 0.18 & 0.86 & 0.53 & 0.85 \\
\hline - more than $15 \%$ up to $50 \%$ & 0.807 & 0.85 & 0.70 & 0.97 & 0.43 & 0.63 & 0.58 & 0.33 & 0.78 & 0.88 \\
\hline - more than $50 \%$ & 0.464 & 0.55 & 0.36 & 0.44 & 0.75 & 0.35 & 0.26 & 0.49 & 0.13 & 0.61 \\
\hline \multicolumn{11}{|c|}{$\begin{array}{l}\text { Technical state of the plant and machinery, } \\
\text { furniture and office equipment (Ref: state of the art) }\end{array}$} \\
\hline - rather new & 0.684 & 0.76 & 0.63 & 0.61 & 0.71 & 0.79 & 0.60 & 0.90 & 0.59 & 0.41 \\
\hline - medium or worse & 0.953 & 0.61 & 0.61 & 0.86 & 0.84 & 0.85 & 1.00 & 0.87 & 0.87 & 0.51 \\
\hline Share of qualified employees (in \%) & 0.029 & 0.30 & 0.42 & 0.04 & 0.91 & 0.02 & 0.99 & 0.46 & 0.87 & 1.00 \\
\hline Further training $(1=$ yes, $0=$ no $)$ & 0.276 & 0.14 & 0.55 & 0.38 & 0.02 & 0.96 & 0.06 & 0.44 & 0.14 & 0.11 \\
\hline \multicolumn{11}{|c|}{$\begin{array}{l}\text { Expected development of the business volume (Ref: } \\
\text { increasing) }\end{array}$} \\
\hline - remaining constant & 0.319 & 0.68 & 0.70 & 0.46 & 0.57 & 0.20 & 0.06 & 0.86 & 0.60 & 0.33 \\
\hline - decreasing & 0.605 & 0.37 & 0.52 & 0.67 & 0.91 & 0.83 & 0.15 & 0.67 & 0.64 & 0.35 \\
\hline \multicolumn{11}{|l|}{ Establishment size (Ref: 1-9 employees) } \\
\hline - 10-49 employees & 0.09 & 0.06 & 0.00 & 0.02 & 0.14 & 0.02 & 0.24 & 0.08 & 0.04 & 0.34 \\
\hline - 50-249 employees & 0.754 & 0.32 & 0.25 & 0.50 & 0.67 & 0.57 & 0.90 & 0.82 & 0.06 & 0.44 \\
\hline
\end{tabular}




\begin{tabular}{|c|c|c|c|c|c|c|c|c|c|c|}
\hline - 250-499 employees & 0.001 & 0.00 & 0.00 & 0.00 & 0.00 & 0.01 & 0.01 & 0.03 & 0.00 & 0.00 \\
\hline - 500 or more employees & 0.367 & 0.45 & 0.08 & 0.05 & 0.22 & 0.16 & 0.08 & 0.26 & 0.16 & 0.29 \\
\hline Wage per full-time-equivalent (log.) & 0.732 & 0.17 & 0.08 & 0.26 & 0.13 & 0.30 & 0.12 & 0.65 & 0.00 & 0.13 \\
\hline West-Germany ( $1=$ yes, $0=$ no) & 0.019 & 0.01 & 0.24 & 0.01 & 0.49 & 0.12 & 0.02 & 0.02 & 0.76 & 0.60 \\
\hline \multicolumn{11}{|l|}{ Sector (Ref: Energy supply, mining and quarrying) } \\
\hline - Manufacturing of food products & 0.887 & 0.90 & 0.93 & 0.77 & 0.35 & 0.16 & 0.97 & 0.05 & 0.23 & 0.93 \\
\hline - Manufacturing of commodities & 0.222 & 0.50 & 0.41 & 0.19 & 0.76 & 0.05 & 0.10 & 0.23 & 0.58 & 0.95 \\
\hline - Manufacturing of durables & 0.223 & 0.30 & 0.81 & 0.26 & 0.10 & 0.91 & 0.57 & 0.97 & 0.07 & 0.35 \\
\hline - Manufacturing of investment- $\&$ consumer goods & 0.201 & 0.28 & 0.96 & 0.14 & 0.10 & 0.91 & 0.73 & 0.78 & 0.08 & 0.20 \\
\hline - Construction & 0.013 & 0.04 & 0.18 & 0.01 & 0.01 & 0.21 & 0.35 & 0.73 & 0.01 & 0.09 \\
\hline
\end{tabular}




\section{References}

ACS Z. J., AUDRETSCH D. B. and FELDMAN M. (1992) Real Effects of Academic Research: Comment, American Economic Review 82, 363-367;

ANDERSSON M. and EJERMO O. (2004) Sectoral Knowledge Production in Swedish Regions 19931999, in Charlie Karlsson, Per Flensburg and Sven Åke Hörte (eds.), Knowledge Spillovers and Knowledge Management, 143-170. Edward Elgar, Cheltenham.

ANSELIN L., VARGA A. and ACS Z. J. (1997) Local Geographic Spillovers between University Research and High Technology Innovations, Journal of Urban Economics 42, 422-448;

ASHEIM, B.T., SMITH, H.L. and OUGHTON, C. (2011) Regional Innovation Systems: Theory, Empirics and Policy, Regional Studies, 45, 875-891;

AUDRETSCH D.B. and FELDMAN M.P. (1996) R\&D Spillovers and the Geography of Innovation and Production, The American Economic Review, 86(3), 630-640;

AUTANT-BERNARD C. (2001) Science and knowledge flows: evidence from the French case, Research Policy 30, 1069-1078;

BARRIO-CASTRO T. D. and GARCIA-QUEVEDO J. (2005) Effects of university research on the geography of innovation, Regional Studies 39, 1217-1229;

BELDERBOS R., CARREE M., DIEDEREN B., LOKSHIN B. and VEUGELERS R. (2004) Heterogeneity in R\&D cooperation strategies, International Journal of Industrial Organization, 22(8-9), 1237-1263;

BLIEN U. (2005) Die Mehrebenenanalyse regionaler Fragestellungen, in GRÖZINGER G. and MATIASKE W. (Eds) Deutschland regional, pp. 133 -156. Mering, München.

BLIND K .and GRUPP H. (1999) Interdependencies between the science and technology infrastructure and innovation activities in German regions: empirical findings and policy consequences, Research Policy 28, 451-468;

BROEKEL T. (2011) Do Cooperative R\&D Subsidies Stimulate Regional Innovation Efficiency? Evidence from Germany. Paper presented on Paper presented at the DIME Final Conference, 6-8 April 2011, Maastrich.

CABAGNOLS A. and LE BAS C. (2002) Differences in the determinants of product and process innovations: The French case, in KLEINKNECHT A. and MOHNEN P. (EDS) Innovation and Firm Performance: Econometric Explorations of Survey Data, pp. 112-149. Palgrave, Hampshire/New York.

CAMERON A. C. and MILLER L. D. (2010) Robust Inference with Clustered Data, in ULLAH A. and GILES D. E. A. (Eds) Handbook of Empirical Economics and Finance, 1- 28. Boca Raton.

CASSIMAN B. and VEUGELERS R. (2006) In search of complementarity in innovation strategy: Internal R\&D and external knowledge acquisition, Management Science 52 (1), 68-82;

COHEN W. (2010) Fifty years of empirical studies of innovative activity and performance. Handbook in Economics, Volume 01, Cambridge, Mass: National Bureau of Economic Research. 
COOKE P. (2001) Strategies for Regional Innovation Systems: Learning Transfer and Applications, Prepared for UNIDO World Industrial Development Report (WIDR), Centre for Advanced Studies Cardiff University, Cardiff CF10 3BB;

CZARNITZKI D. and HOTTENROTT H. (2009) Are local milieus the key to innovation performance, Journal of Regional Science 49(1), 81-112;

DE DOMINICIS L., FLORAX R. J. G. M. and DE GROOT H. L. F. (2011) Regional Clusters of Innovative Activity in Europe: Are Social Capital and Geographical Proximity the Key Determinants?. Tinbergen Institute Discussion Paper, TI 2011-009/3, Tinbergen;

DOLOREUX D. and PARTO, S. (2005) Regional innovation systems: Current discourse and unresolved issues, Technology in society $27(2), 133-153$;

ECKEY H.-F., KOSFELD R. and TÜRCK M. (2006) Abgrenzung deutscher Arbeitsmarktregionen, Raumforschung und Raumordnung 64(4), 299 -309;

FELDMAN M. P. (1994) The Geography of Innovation. Kluwer, Boston, MA.

FISCHER G., JANIK F., MÜLLER D. and SCHMUCKER A. (2009) The IAB Establishment Panel - things users should know, Schmollers Jahrbuch. Zeitschrift für Wirtschafts- und Sozialwissenschaften 129(1), 133-148;

FISCHER M. and VARGA A. (2003) Spatial Knowledge Spillovers and University Research: Evidence from Austria, Annals of Regional Science 37, 303-322;

FRITSCH M. and FALCK O. (2007) New Business Formation by Industry over Space and Time: A Multidimensional Analysis, Regional Studies 41(2), 157-172;

FRITSCH M. and KAUFFELD-MONZ M. (2010) The impact of network structure on knowledge transfer:an application of social network analysis in the context of regional innovation networks, Annals of Regional Science, 44, 21-38;

FRITSCH M. and SLAVTCHEV V. (2011) Determinants of the Efficiency of Regional Innovation Systems, Regional Studies 45, 905-918;

FRITSCH M. and SLAVTCHEV V. (2007) Universities and Innovation in space, Industry and Innovation 14, 201-218;

GREUNZ L. (2003) Geographically and technologically mediated knowledge spillovers between European regions, Annals of Regional Science 37, 657-680;

JAFFE A. B. (1989) Real Effects of Academic Research, American Economic Review 79, 957-970;

KAISER U. (2002) An empirical test of models explaining research expenditures and research cooperation: evidence for the German service sector, International Journal of Industrial Organization 20(6), 747-774;

KAUFFELD-MONZ M. and FRITSCH M. (2010) Who are the Knowledge Brokers in Regional Systems of Innovation? A Multi-Actor Network Analysis. Regional Studies, First published on: 05 July 2010 (iFIrst) 
KOSFELD R. and WERNER A. (2012) Deutsche Arbeitsmarktregionen - Neuabgrenzung nach den Kreisgebietsreformen 2007-2011. Raumforschung und Raumordnung 70(1), 49-64;

KROPP P. and SCHWENGLER B. (2012) Vergleich von funktionalen Arbeitsmarktabgrenzungen in Deutschland, Sozialer Fortschritt 61(1), 11-20;

KROPP P. and SCHWENGLER B. (2011) Abgrenzung von Arbeitsmarktregionen - ein Methodenvorschlag, Raumforschung und Raumordnung 69(1), 45 - 62;

LOKSHIN B., BELDERBOS R. and CARREE M. (2008) The productivity effects of internal and external R\&D: Evidence from a dynamic panel data model, Oxford Bulletin of Economics and Statistics 70 (3), 399-413;

MAIRESSE J. and MOHNEN P. (2010) Using innovations surveys for econometric analysis. Handbook of Economics, Volume 02, Cambridge, Mass: National Bureau of Economic Research.

MARTINEZ-ROS E. and LABEAGA J. (2002) Modelling innovation activities using discrete choice panel data models; in KLEINKNECHT A. and MOHNEN P. (EDS) Innovation and firm performance: Econometric explorations of survey data, pp. 150-171. Palgrave, New York.

MIOTTI L. and SACHWALD F. (2003) Co-operative R\&D: why and with whom? An integrated framework of analysis. Research Policy 32(8), 1481-1499;

MIRAVETE E. and PERNIAS, J. (2006) Innovation complementarity and scale of production, Journal of Industrial Economics 54, 1-29;

MORENO R., PACI R. and USAI S. (2005) Geographical and sectoral clusters of innovation in Europe, Annals of Regional Science 39, 715-739;

MOULTON, B. R. (1990) An illustration of a pitfall in estimation the effects of aggregate variables on micro units, Review of Economics and Statistics 72, $334-338$;

MOULTON B. R. (1986) Random group effects and the precision of regression estimates, Journal of Econometrics 32, $385-397$;

ORGANISATION FOR ECONOMIC CO-OPERATION AND DEVELOPMENT (2005) Oslo manual: Guidelines for collecting and interpreting innovation data. Paris: OECD.

PACI R. and USAI S. (2000) The role of specialization and diversity externalities in the agglomeration of innovative activities, Rivista Italiana degli Economisti 2, 237-268;

PACI R. and USAI S. (1999) Externalities, knowledge spillovers and the spatial distribution of innovation, GeoJournal 49, 381-390;

PIERGIOVANNI R. and SANTARELLI E. (2001) Patents and the Geographic Localization of R\&D Spillovers in French Manufacturing, Regional Studies 35, 697-702;

PIERGIOVANNI R., SANTARELLI E. and VIVARELLI M. (1997) From which source do small firms derive their innovative inputs? Some evidence from Italian industry, Review of Industrial Organization 12, $243-258$ 
POLDER M., VAN LEEUWEN G., MOHNEN P. and RAYMOND W. (2009) Productivity Effects of Innovation Modes, Statistics Netherlands Working Paper 09033, Amsterdam.

RABE-HESKETH S. and SKRONDAL A. (2012) Multilevel and Longitudinal Modeling Using Stata, Volume I+II, Stata Press, Texas.

RONDE P. and HUSSLER C. (2005) Innovation in Regions: What Does Really Matter?, Research Policy 34, 1150-1172;

ROPER S. and LOVE J. (2002) Innovation and export performance: evidence from the UK and German manufacturing plants, Research Policy 31(7), 1087-1102;

SMITH H. L. and WATERS R. (2011) Scientific Labour Markets, Networks and Regional Innovation Systems, Regional Studies, 45, 961-976;

SRHOLEC M. (2010) A Multilevel Approach to Geography of Innovation, Regional Studies 44, 12071220;

STERNBERG R. and ARNDT O. (2001) The firm or the region: what determinates the innovation behavior of European firms?, Economic Geography 77(4), 364-382;

TETHER B. (2002) Who co-operates for innovation and why? An empirical analysis, Research Policy 31(6), 947-967;

VEUGELERS R. (1997) Internal R\&D Expenditures and External Technology Sourcing, Research Policy 26, 303-315; 


\section{Tables}

Table 1: Innovations in Germany in the secondary sector

\begin{tabular}{|llrrr|}
\hline & & \multicolumn{3}{c}{ Business Year } \\
\cline { 2 - 5 } & & 2007 & 2008 & 2009 \\
\hline Innovations & Share & $39 \%$ & $40 \%$ & $37 \%$ \\
\cline { 2 - 5 } & Frequencies & 2,106 & 2,094 & 2,058 \\
\hline Radical innovations & Share & $5 \%$ & $7 \%$ & $6 \%$ \\
\cline { 2 - 5 } & Frequencies & 451 & 438 & 433 \\
\hline Imitations & Share & $16 \%$ & $19 \%$ & $18 \%$ \\
\hline Incremental & Frequencies & 955 & 1,004 & 991 \\
\hline innovations & Share & $33 \%$ & $32 \%$ & $30 \%$ \\
\hline Process innovations & Frequencies & 1,852 & 1,811 & 1,756 \\
\hline & Share & $13 \%$ & $11 \%$ & $11 \%$ \\
\hline & Frequencies & 912 & 859 & 838 \\
\hline
\end{tabular}

Note: Share is extrapolated.

Source: IAB Establishment Panel Survey 2006-2010 
Table 2: Amount of Innovations in Germany in the secondary sector

\begin{tabular}{|c|c|c|}
\hline $\begin{array}{l}\text { Amount of } \\
\text { Innovation } \\
\text { types }\end{array}$ & Frequencies & Share \\
\hline 0 & 5,209 & $46 \%$ \\
\hline 1 & 2,407 & $21 \%$ \\
\hline 2 & 2,119 & $19 \%$ \\
\hline 3 & 1,172 & $10 \%$ \\
\hline 4 & 518 & $5 \%$ \\
\hline Sum & 11,425 & $100 \%$ \\
\hline
\end{tabular}

Note: Due to rounding differences the sum does not add up to exactly to $100 \%$.

Source: IAB Establishment Panel Survey 2008-2010 
Table 3: Rank-Order of Innovation Combos in Germany in the secondary sector

\begin{tabular}{|c|c|c|c|r|r|}
\hline $\begin{array}{l}\text { Radical } \\
\text { Innovation }\end{array}$ & Imitation & $\begin{array}{l}\text { Incremental } \\
\text { Innovation }\end{array}$ & $\begin{array}{l}\text { Process } \\
\text { Innovation }\end{array}$ & Frequencies & Rank \\
\hline- & - & - & - & 5,209 & 1 \\
\hline- & - & + & - & 1,721 & 2 \\
\hline- & + & + & - & 1,007 & 3 \\
\hline- & - & + & + & 792 & 4 \\
\hline+ & + & + & + & 696 & 5 \\
\hline- & + & + & + & 518 & 6 \\
\hline+ & - & + & + & 245 & 7 \\
\hline- & - & - & + & 242 & 9 \\
\hline+ & + & + & - & 212 & 10 \\
\hline+ & - & + & - & 196 & 11 \\
\hline- & + & - & + & 53 & 12 \\
\hline+ & - & - & - & 51 & 13 \\
\hline+ & + & - & - & 42 & 14 \\
\hline+ & - & - & + & 15 & 16 \\
\hline+ & + & - & + & -29 & \\
\hline
\end{tabular}

Source: IAB Establishment Panel Survey 2008-2010 
Table 4: Determinants of innovations in the business years 2006-2009 (Marginal Effects)

\begin{tabular}{|c|c|c|c|c|c|c|c|c|c|c|c|c|c|c|c|}
\hline \multirow{2}{*}{$\begin{array}{l}\text { Binomial Multilevel-Model } \\
\text { dependent variable: ( } 1=y e s, 0=\text { non-innovator) }\end{array}$} & \multicolumn{3}{|c|}{ Innovation } & \multicolumn{3}{|c|}{ Process Innovation } & \multicolumn{3}{|c|}{ Radical Innovation } & \multicolumn{3}{|c|}{$\begin{array}{l}\text { Incremental } \\
\text { Innovation }\end{array}$} & \multicolumn{3}{|c|}{ Imitation } \\
\hline & $\mathrm{dy} / \mathrm{dx}$ & & S. E. & $\mathrm{dy} / \mathrm{dx}$ & & S. E. & $d y / d x$ & & S. E. & $d y / d x$ & & S. E. & $d y / d x$ & & S. E. \\
\hline $\begin{array}{l}\text { Fixed Part - establishment level } \\
\text { R\&D (Ref: no R\&D in establishment) }\end{array}$ & & & & & & & & & & & & & & & \\
\hline R\&D in establishment without cooperation & 0.245 & $* * *$ & 0.187 & 0.210 & $* * *$ & 0.231 & 0.277 & $* * *$ & 0.259 & 0.272 & $* * *$ & 0.190 & 0.251 & $* * *$ & 0.215 \\
\hline $\begin{array}{l}\text { R\&D in establishment with cooperation } \\
\text { Share of plant-expansion investment on total } \\
\text { investments (Ref: no plant-expansion investment) }\end{array}$ & 0.275 & $* * *$ & 0.104 & 0.309 & $* * *$ & 0.121 & 0.300 & $* * *$ & 0.144 & 0.301 & $* * *$ & 0.107 & 0.293 & $* * *$ & 0.119 \\
\hline - up to $40 \%$ & 0.087 & $* * *$ & 0.090 & 0.146 & $* * *$ & 0.119 & 0.088 & $* * *$ & 0.152 & 0.093 & $* * *$ & 0.095 & 0.096 & $* * *$ & 0.109 \\
\hline - more than $40 \%$ up to $90 \%$ & 0.068 & $* * *$ & 0.087 & 0.111 & $* * *$ & 0.113 & 0.062 & $* * *$ & 0.142 & 0.073 & $* * *$ & 0.092 & 0.079 & $* * *$ & 0.105 \\
\hline $\begin{array}{l}\text { - more than } 90 \% \\
\text { Export share on sales (Ref: no export) }\end{array}$ & 0.027 & & 0.095 & 0.066 & $* * *$ & 0.130 & 0.028 & & 0.165 & 0.018 & & 0.102 & 0.052 & $* *$ & 0.113 \\
\hline - up to $15 \%$ & 0.038 & $* *$ & 0.091 & 0.058 & $* * *$ & 0.123 & 0.042 & $* *$ & 0.155 & 0.035 & $*$ & 0.097 & 0.050 & $* *$ & 0.111 \\
\hline - more than $15 \%$ up to $50 \%$ & 0.077 & $* * *$ & 0.103 & 0.089 & $* * *$ & 0.132 & 0.059 & $* * *$ & 0.165 & 0.072 & $* * *$ & 0.109 & 0.088 & $* * *$ & 0.124 \\
\hline $\begin{array}{l}\text { - more than } 50 \% \\
\text { Technical state of the plant and machinery, } \\
\text { furniture and office equipment (Ref: state of the } \\
\text { art) }\end{array}$ & 0.114 & $* * *$ & 0.145 & 0.104 & $* * *$ & 0.176 & 0.081 & $* * *$ & 0.215 & 0.120 & $* * *$ & 0.150 & 0.114 & $* * *$ & 0.171 \\
\hline - rather new & -0.025 & & 0.085 & -0.047 & $* *$ & 0.113 & -0.040 & $* *$ & 0.141 & -0.032 & $*$ & 0.090 & -0.038 & $*$ & 0.102 \\
\hline - medium or & -0.073 & $* * *$ & 0.091 & -0.332 & $* * *$ & 0.124 & -0.456 & $* * *$ & 0.154 & -0.111 & $* * *$ & 0.096 & -0.264 & $* * *$ & 0.109 \\
\hline Share of qualified employees (in \%) & 0.003 & $* * *$ & 0.001 & 0.000 & & 0.002 & 0.001 & & 0.003 & 0.003 & & 0.002 & 0.002 & & 0.002 \\
\hline $\begin{array}{l}\text { Further training ( } 1=\text { yes, } 0=\text { no) } \\
\text { Expected development of the business volume } \\
\text { (Ref: increasing) }\end{array}$ & 0.071 & $* * *$ & 0.067 & 0.082 & $* * *$ & 0.099 & 0.057 & $* * *$ & 0.126 & 0.073 & $* * *$ & 0.072 & 0.083 & $* * *$ & 0.082 \\
\hline - remaining constant & -0.033 & $* *$ & 0.070 & -0.042 & $* *$ & 0.098 & -0.032 & $* *$ & 0.123 & -0.035 & $* *$ & 0.074 & -0.041 & $* *$ & 0.085 \\
\hline - decreasing & -0.049 & $* * *$ & 0.078 & -0.303 & $* * *$ & 0.109 & -0.444 & $* * *$ & 0.136 & -0.094 & $* * *$ & 0.083 & -0.238 & $* * *$ & 0.095 \\
\hline
\end{tabular}




\begin{tabular}{|c|c|c|c|c|c|c|c|c|c|c|c|c|c|c|c|}
\hline \multirow{2}{*}{$\begin{array}{l}\text { Binomial Multilevel-Model } \\
\text { dependent variable: ( } 1=y e s, 0=\text { non-innovator) }\end{array}$} & \multicolumn{3}{|c|}{ Innovation } & \multicolumn{3}{|c|}{ Process Innovation } & \multicolumn{3}{|c|}{ Radical Innovation } & \multicolumn{3}{|c|}{$\begin{array}{l}\text { Incremental } \\
\text { Innovation }\end{array}$} & \multicolumn{3}{|c|}{ Imitation } \\
\hline & $\mathrm{dy} / \mathrm{dx}$ & & S. E. & $\mathrm{dy} / \mathrm{dx}$ & & S. E. & $\mathrm{dy} / \mathrm{dx}$ & & S. E. & $\mathrm{dy} / \mathrm{dx}$ & & S. E. & $\mathrm{dy} / \mathrm{dx}$ & & S. E. \\
\hline \multicolumn{16}{|l|}{ Establishment size (Ref: 1-9 employees) } \\
\hline - 10-49 employees & 0.053 & $* * *$ & 0.079 & 0.054 & $* * *$ & 0.123 & 0.036 & $* *$ & 0.157 & 0.052 & $* * *$ & 0.085 & 0.037 & $* *$ & 0.099 \\
\hline - 50-249 employees & 0.112 & $* * *$ & 0.103 & 0.131 & $* * *$ & 0.147 & 0.094 & $* * *$ & 0.187 & 0.116 & $* * *$ & 0.109 & 0.091 & $* * *$ & 0.125 \\
\hline - 250-499 employees & 0.210 & $* * *$ & 0.183 & 0.272 & $* * *$ & 0.223 & 0.163 & $* * *$ & 0.285 & 0.218 & $* * *$ & 0.190 & 0.191 & $* * *$ & 0.214 \\
\hline - 500 or more employees & 0.181 & $* * *$ & 0.199 & 0.273 & $* * *$ & 0.238 & 0.167 & $* * *$ & 0.298 & 0.198 & $* * *$ & 0.206 & 0.150 & $* * *$ & 0.235 \\
\hline Wage per full-time-equivalent (log.) & -0.029 & & 0.073 & 0.100 & & 0.110 & -0.149 & & 0.135 & -0.019 & & 0.078 & -0.123 & & 0.089 \\
\hline West-Germany ( $1=y e s, 0=$ no) & -0.004 & & 0.163 & -0.019 & & 0.219 & -0.067 & $* *$ & 0.237 & 0.001 & & 0.178 & -0.004 & & 0.180 \\
\hline \multicolumn{16}{|l|}{ Sector (Ref: Energy supply, mining and quarrying) } \\
\hline - Manufacturing of food products & 0.243 & $* * *$ & 0.194 & 0.213 & $* * *$ & 0.277 & 0.210 & $* * *$ & 0.381 & 0.273 & $* * *$ & 0.212 & 0.327 & $* * *$ & 0.253 \\
\hline - Manufacturing of commodities & 0.229 & $* * *$ & 0.191 & 0.225 & $* * *$ & 0.270 & 0.165 & $* * *$ & 0.384 & 0.268 & $* * *$ & 0.209 & 0.255 & $* * *$ & 0.254 \\
\hline - Manufacturing of durables & 0.159 & $* * *$ & 0.175 & 0.146 & $* * *$ & 0.248 & 0.118 & $* * *$ & 0.359 & 0.190 & $* * *$ & 0.193 & 0.174 & $* * *$ & 0.236 \\
\hline goods & 0.183 & $* * *$ & 0.170 & 0.169 & $* * *$ & 0.241 & 0.126 & $* * *$ & 0.351 & 0.218 & $* * *$ & 0.187 & 0.189 & $* * *$ & 0.230 \\
\hline - Construction & 0.046 & & 0.171 & 0.019 & & 0.249 & 0.017 & & 0.364 & 0.071 & $*$ & 0.189 & 0.090 & $* *$ & 0.232 \\
\hline Constant & -0.949 & & 0.683 & -2.665 & $* * *$ & 0.979 & -1.681 & & 1.152 & -1.319 & $*$ & 0.739 & -1.486 & $*$ & 0.805 \\
\hline \multicolumn{16}{|l|}{ Fixed Part - regional level } \\
\hline UR: Unemployment Rate & -0.026 & & 0.018 & -0.045 & $*$ & 0.024 & -0.085 & $* * *$ & 0.026 & -0.029 & & 0.020 & -0.014 & & 0.020 \\
\hline RTC: Research and Technology Center & 0.001 & & 0.101 & -0.113 & & 0.133 & 0.043 & & 0.138 & -0.011 & & 0.110 & 0.022 & & 0.108 \\
\hline MINTALLE: Share of MINT-graduates & 0.002 & & 0.002 & 0.005 & $*$ & 0.003 & 0.008 & $* * *$ & 0.003 & 0.002 & & 0.003 & 0.004 & & 0.003 \\
\hline \multicolumn{16}{|l|}{ Random Effects Parameters } \\
\hline Level 3: Region & 0.126 & $* * *$ & 0.034 & 0.195 & $* * *$ & 0.057 & 0.102 & $*$ & 0.055 & 0.159 & $* * *$ & 0.041 & 0.102 & $* * *$ & 0.036 \\
\hline Level 2: Establishment & 0.884 & $* * *$ & 0.075 & 1.018 & $* * *$ & 0.126 & 1.256 & $* * *$ & 0.177 & 0.952 & $* * *$ & 0.083 & 1.044 & $* * *$ & 0.102 \\
\hline Number of groups (regions) & 138 & & & 137 & & & 135 & & & 138 & & & 135 & & \\
\hline Number of groups (firms) & 4099 & & & 3342 & & & 2892 & & & 3970 & & & 3404 & & \\
\hline Observations & 8735 & & & 5898 & & & 4928 & & & 8055 & & & 6217 & & \\
\hline
\end{tabular}

$* * * p<0.01, * * p<0.05, * p<0.1$, Source: IAB Establishment Panel Survey 2006-2010 
Table 5: Determinants of the combinations of innovations in the business years 2006-2009 (Marginal Effects)

\begin{tabular}{|c|c|c|c|c|c|c|c|c|c|c|}
\hline \multirow[t]{2}{*}{$\begin{array}{l}\text { Binomial Multilevel-Model } \\
\text { dependent variable: ( } 1=y e s, 0=\text { non-innovator) }\end{array}$} & \multicolumn{2}{|c|}{$\begin{array}{l}\text { Combo 1: } \\
\text { only incremental } \\
\text { innovations }\end{array}$} & \multicolumn{2}{|c|}{$\begin{array}{l}\text { Combo 2: } \\
\text { incremental } \\
\text { innovations + } \\
\text { imitations }\end{array}$} & \multicolumn{2}{|c|}{$\begin{array}{l}\text { Combo 3: } \\
\text { incremental + } \\
\text { process innovations }\end{array}$} & \multicolumn{2}{|c|}{\begin{tabular}{|c|} 
Combo 4: \\
incremental + \\
process innovations \\
+ imitations \\
\end{tabular}} & \multicolumn{2}{|c|}{$\begin{array}{c}\text { Combo 5: } \\
\text { all } 4 \text { innovation types }\end{array}$} \\
\hline & $\mathrm{dy} / \mathrm{dx}$ & S.E. & $\mathrm{dy} / \mathrm{dx}$ & S.E. & $\mathrm{dy} / \mathrm{dx}$ & S. E. & $\mathrm{dy} / \mathrm{dx}$ & S.E. & $\mathrm{dy} / \mathrm{dx}$ & S. E. \\
\hline \multicolumn{11}{|l|}{$\begin{array}{l}\text { Fixed Part - establishment level } \\
\text { R\&D (Ref: no R\&D in establishment) }\end{array}$} \\
\hline R\&D in establishment without cooperation & $0.502 * * *$ & 0.274 & $0.393 * * *$ & 0.224 & $0.142 * * *$ & 0.071 & $0.215 * * *$ & 0.137 & $0.184 * * *$ & 0.143 \\
\hline $\begin{array}{l}\text { R\&D in establishment with cooperation } \\
\text { Share of plant-expansion investment on total } \\
\text { investments (Ref: no plant-expansion investment) }\end{array}$ & $0.476 * * *$ & 0.248 & $0.397 * * *$ & 0.228 & $0.233 * * *$ & 0.162 & $0.264 * * *$ & 0.186 & $0.207 * * *$ & 0.166 \\
\hline - up to $40 \%$ & $0.303 * *$ & 0.054 & $0.238 * * *$ & 0.066 & $0.121 * * *$ & 0.049 & $0.160 * * *$ & 0.084 & $0.095 * * *$ & 0.055 \\
\hline - more than $40 \%$ up to $90 \%$ & 0.280 & 0.031 & $0.220 * *$ & 0.048 & $0.096 * * *$ & 0.024 & $0.136 * * *$ & 0.060 & $0.082 * * *$ & 0.042 \\
\hline - more than $90 \%$ & $0.202 * *$ & -0.047 & $0.206 *$ & 0.034 & 0.074 & 0.002 & 0.097 & 0.021 & $0.064 * *$ & 0.024 \\
\hline \multicolumn{11}{|l|}{ Export share on sales (Ref: no export) } \\
\hline - up to $15 \%$ & 0.259 & 0.016 & 0.204 & 0.028 & 0.094 & -0.001 & $0.123 * * *$ & 0.043 & 0.050 & 0.002 \\
\hline - more than $15 \%$ up to $50 \%$ & $0.285 *$ & 0.042 & $0.240 * * *$ & 0.064 & 0.121 & 0.026 & $0.130 * * *$ & 0.050 & 0.062 & 0.014 \\
\hline $\begin{array}{l}\text { - more than } 50 \% \\
\text { Technical state of the plant and machinery, } \\
\text { furniture and office equipment (Ref: state of the } \\
\text { art) }\end{array}$ & $0.332 * * *$ & 0.089 & $0.235 *$ & 0.059 & $0.133 *$ & 0.038 & $0.145 * * *$ & 0.065 & 0.068 & 0.020 \\
\hline - rather new & 0.273 & -0.004 & 0.194 & 0.001 & 0.104 & -0.014 & $0.101 * * *$ & -0.041 & $0.050 * * *$ & -0.030 \\
\hline - medium or worse & $0.223 * * *$ & -0.385 & 0.176 & -0.432 & $0.087 * *$ & -0.521 & $0.067 * * *$ & -0.541 & $0.042 * * *$ & -0.566 \\
\hline Share of qualified employees (in \%) & $0.000 * * *$ & & 0.000 & & 0.000 & & 0.000 & & 0.000 & \\
\hline $\begin{array}{l}\text { Further training }(1=\text { yes, } 0=\text { no) } \\
\text { Expected development of the business volume } \\
\text { (Ref: increasing) }\end{array}$ & $0.272 * * *$ & 0.039 & $0.210 * * *$ & 0.047 & $0.099 * * *$ & 0.036 & $0.109 * * *$ & 0.036 & $0.063 * * *$ & 0.025 \\
\hline - remaining constant & -0.019 & 0.097 & -0.022 & 0.114 & $-0.020 *$ & 0.144 & $-0.027 * *$ & 0.151 & -0.006 & 0.195 \\
\hline - decreasing & $-0.367 * *$ & 0.109 & $-0.424 *$ & 0.128 & $-0.512 * *$ & 0.159 & $-0.518 * * *$ & 0.167 & $-0.561 * *$ & 0.217 \\
\hline
\end{tabular}




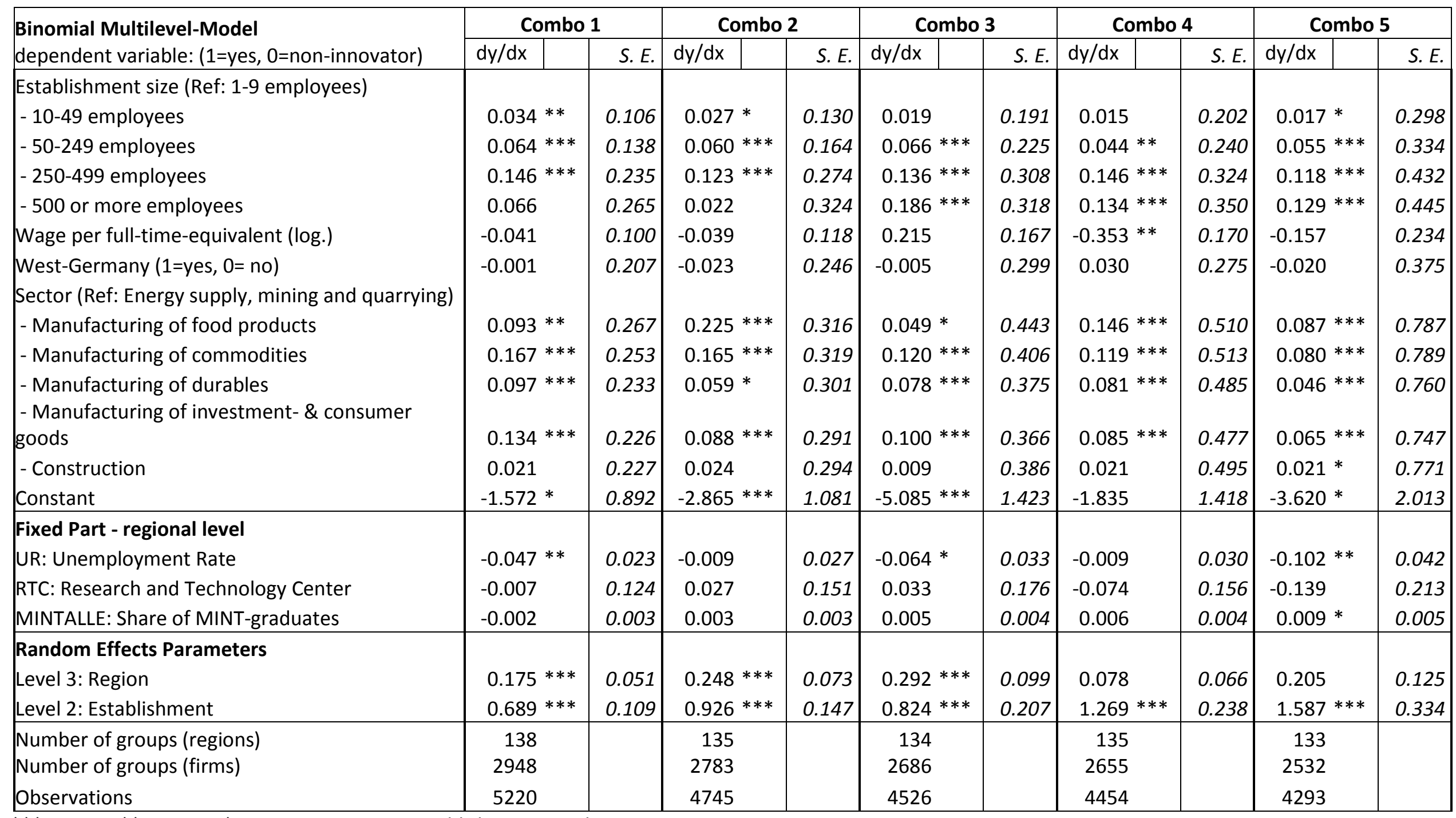

${ }^{* * *} p<0.01,{ }^{* *} p<0.05,{ }^{*} p<0.1$, Source: IAB Establishment Panel Survey 2006-2010 